\title{
A new species of the genus Carcinocephalus Bernhauer (Coleoptera: Staphylinidae: Omaliinae: Omaliini) from Taiwan
}

\author{
Alexey V. SHAVRIN \\ Daugavpils University, Institute of Life Sciences and Technology, Coleopterological Research Center, Vienibas 13, \\ LV-5401, Daugavpils, Latvia; e-mail: ashavrin@hotmail.com
}

\begin{abstract}
A new species of the genus Carcinocephalus Bernhauer, 1903 is described from Taiwan (Chiai Hsien, Alishan): C. szujeckii sp. n. All morphological structures both for male and female are illustrated. The new species is compared with all Holarctic species of the genus.
\end{abstract}

Key words: taxonomy, description, new species, Palaearctic region, Taiwan

\section{INTRODUCTION}

The history of the genus Carcinocephalus Bernhauer, 1903 (Omaliini) was recently provided by Assing (2009) where, based on the study of the type and additional material, he synonymized several European taxa: the subgenus Scribaia Luze, 1906 with the nominal subgenus, C. bosnicus Scheerpeltz, 1934 and C. mehadiensis (Bernhauer, 1902) with C. merkli (Eppelsheim, 1883). To date, Carcinocephalus includes four species: C. blandus (Luze, 1906) and C. merkli (Eppelsheim, 1883) from southern Europe, C. satoi Hayashi, 2007 from Japan and the Nearctic C. flavidus (Hamilton, 1895). Diagnoses and comments on the genus were provided by Scheerpeltz (1934), Székessy (1963), Tóth (1982), Zanetti (1987), Hayashi (2007) and Assing (2009), and some additional data on the morphology of the Nearctic species can be found in Newton et al. (2000). Species of the genus are characterized by the following details of the external morphology, a combination of which distinguishes it from other related genera of the tribe Omaliini: head with elevated frons and vertex, separated from lateral portions of head by very long oblique furrows extending from apical margins of well distinct ocelli to base of antennae; antennomere 7 transverse or nearly as long as wide; disc of pronotum with one deep longitudinal impression each side of midline. Some species are characterized by ophthalmo- and wing-dimorphism (Thayer 1992, Assing 2009).

The aim of this paper is to describe a new species of Carcinocephalus from the Palaearctic Region, which was collected by my colleague A. Smetana (Ottawa) in Taiwan during his trip in April 1990.

In general, the genus requires a comprehensive taxonomic revision as it may include additional taxa from the Nearctic Region (Newton et al. 2000) and some described Palaearctic species require supplementary morphological data, especially of structures of the female genital segment, spermatheca and internal structure of the aedeagus. For these reasons, I did not provide a key for all species of the genus.

\section{MATERIAL AND METHODS}

The examined material is deposited in the following institutions: CSh - collection of A. Shavrin, Daugavpils, Latvia, NSMT - collection of Aleš Smetana deposited at the National Museum of Nature and Science, Toshiba, Japan (S. Nomura). 
Specimens were studied using Nikon SMZ 745T and Nikon Eclipse E200 stereomicroscopes. A digital camera (Sony Alpha DSLR-A300) was used for the photograph and all figures were processed using Adobe Photoshop software. All measurements are given in millimeters and were made with an ocular micrometer mounted on a stereoscopic microscope. Citations of the type labels are separated by a comma; different lines in labels are separated by a vertical line; my comments to the labels are given in square brackets.

\section{Carcinocephalus szujeckii sp. n.}

(Figs 1-10)

Type material examined: Holotype: male [Plastic plate with preparation of aedeagus, abdominal tergite VIII, sternite VIII and apical segment in Canadian balsam pinned under the beetle]: 'TAIWAN Chiai | Hsien, Alishan |2200m 26.IV.1990 | A.Smetana [T25]' [rectangular label, printed], 'HOLOTYPE | Carcinocephalus | szujeckii | Shavrin A. V. des. 2018' [red rectangular label, printed] (NSMT).

Paratypes: 1 male [Antennomeres 10-11 are missing], 1 female [Plastic plate with preparation of abdominal tergite VIII, sternite VIII, apical abdominal segment and spermatheca pinned under the beetle]: male and female with same label data as the holotype; f\# with label: 'Prosopaspis ? [handwritten] | Carcinocephalus ? [handwritten] | M.K.Thayer det. 1998' [rectangular label, printed] (1 female: NSMT, 1 male: CSh). All paratypes with additional label: 'PARATYPE | Carcinocephalus | szujeckii | Shavrin A.V. des. 2018' [red rectangular label, printed].

Description. Measurements $(n=3)$ : maximum width of head including eyes: $0.40-0.41$; length of head (from base of labrum to neck constriction along midline): $0.26-0.28$; ocular length (longitudinal): $0.12-0.13$; length/width of segment III of maxillary palpus: $0.05 / 0.02$; length/width of segment IV of maxillary palpus: $0.06 / 0.01$; length of antenna: 0.44 ; length of pronotum: $0.30-0.31$; maximum width of pronotum: $0.50-0.51$; sutural length of elytra (length of elytra from the apex of scutellum to the posterior margin of sutural angle): $0.63-0.65$; maximum width of elytra: 0.67-0.70; width of abdominal segment IV: $0.64-0.67$; length of aedeagus: 0.41 ; length of hind tibia: 0.26 ; length of hind tarsi: 0.13 (tarsomeres 1-4: 0.05 ; tarsomere 5: 0.08 ); total length of body (from anterior margin of clypeus to apex of abdomen): $1.70-1.98$ (holotype).

Habitus as in Fig. 1. Body relatively elongated, moderately convex. Head and abdominal tergites IV-VII dark brown; antennomeres 8-11, pronotum and paratergites castaneous brown; elytra yellowish-brown; anterolateral portions of clypeus under antennal insertion, mouthparts, antennomeres $1-7$, basal margin of pronotum, apical margin of abdominal tergite VII, tergite VIII and apical abdominal segment yellow to reddish-yellow. Middle elevation of head with very sparse and irregular small punctures; punctation of pronotum moderately large, irregular, markedly denser on middle portion, with wide impunctate lateral portions and small transverse area in basal part of pronotum; scutellum without punctures; metasternum with sparse moderately large punctation; elytra with very small punctation, punctures arranged to indistinct rows more or less parallel in middle part of each elytron, narrow basal and latero-basal portions of elytra with more distinct small and sparse punctation; abdomen with small indistinct punctation. Body glossy, with dense transverse microsculpture on middle elevation of head, with more irregular longitudinal microsculpture between ocelli and ocellus and eyes; pronotum with dense transverse moderately coarse microsculpture, lateral portions of pronotum and metasternum with longitudinal microsculpture; scutellum with small well visible isodiametric microsculpture; elytra with strong coriaceous microsculpture, more gentle in posterior portion; abdominal tergites (except paratergites) with well distinct transverse and cellular 
microsculpture. Pubescence of middle elevation of head irregular, sparse and short; pronotum and elytra with sparser and more regular erected pubescence than that on head; abdomen with sparse short accumbent pubescence.

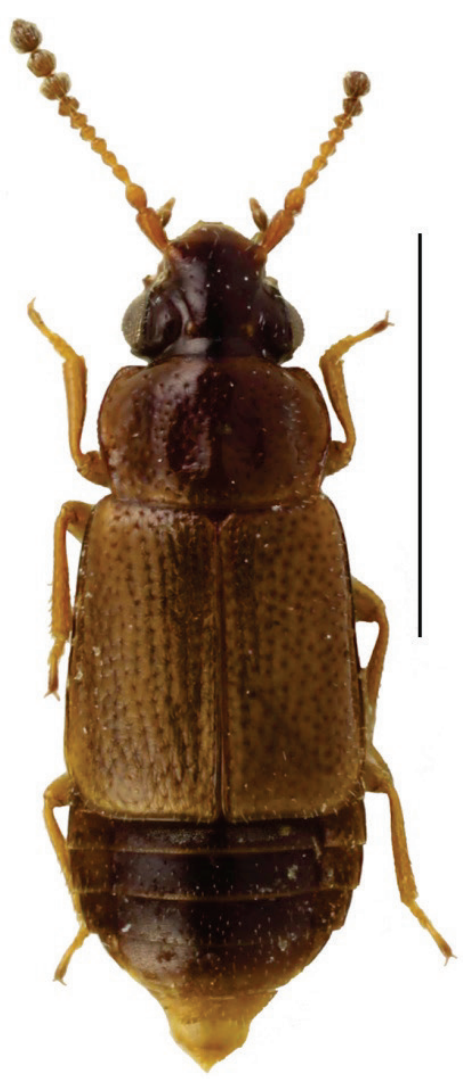

Fig. 1. Habitus (paratype) of Carcinocephalus szujeckii, sp. n. Scale bar: $1.00 \mathrm{~mm}$.

Head 1.4-1.5 times as broad as long, with shield-like distinctly elevated trapezoidal middle portion, narrowing to basal part between two oblique markedly deep furrows reaching anterior margin of ocelli. Laterobasal portions of head between eyes and ocelli slightly convex, with moderately wide smoothed surface along each furrow. Anterolateral portions of head between antennal insertion and anterior margin of eye deeply concaved. Eyes large and convex; thin and markedly elevated infraorbital ridge beginning from antennal insertion, framing dorsal margins of eyes and stretching to posterior margins of eyes; infraorbital ridges in middle parallel to each other (if see from above). Postocular ridge small; surface between postocular ridge and posterior margin of eye as long as two nearest facets; temples very short. Ocelli large, located at level of hind margins of eyes, distance between ocelli one and half times less than distance between ocellus and posterior margin of eye; neck constriction marked with transverse occipital furrow. Last segment of maxillar palpus gradually narrowing apicad, twice narrower and slightly longer than slightly swollen penultimate segment. Antenna moderately short, reaching basal part of pronotum when reclined; basal antennomere twice as long as wide, distinctly wider than oval antennomere 2, antennomere 3 with narrow elongated basal portion, antennomere 4 slightly longer than wide, antennomeres 5-6 small and round, antennomeres 
7-11 distinctly transverse, apical four antennomeres forming indistinct loose club; measurements of antennomeres (length/width; holotype): $1: 0.08 \times 0.04 ; 2: 0.06 \times 0.03 ; 3: 0.05$ $\times 0.02 ; 4: 0.03 \times 0.02 ; 5-6: 0.02 \times 0.02 ; 7: 0.02 \times 0.03 ; 8: 0.03 \times 0.04 ; 9: 0.03 \times 0.05 ; 10: 0.03$ $\times 0.06 ; 11: 0.07 \times 0.06$.

Pronotum transverse, 1.5-1.6 times as broad as long, 1.2 times as wide as head, from widest middle slightly more narrowed posteriad than anteriad, with markedly convex middle portion; anterior margin rounded, about as wide as posterior margin; anterior angles slightly protruded; posterior angles obtuse; lateroapical and lateral margins distinctly bordered; middle portion with two wide, elongated and moderately deep impressions; lateral portions with wide and deep oval impressions.

Elytra slightly convex, distinctly longer than pronotum and slightly broader than long, lateral sides slightly and narrowly explanate in middle; lateral margins bordered, more or less parallel-sided or indistinctly widened posteriad; posterior margins of elytra straight. Wings fully developed.

Legs moderately long; protarsomeres and femora dimorphic; tarsi with long clavate adhesive setae, distinctly longer on protarsi.
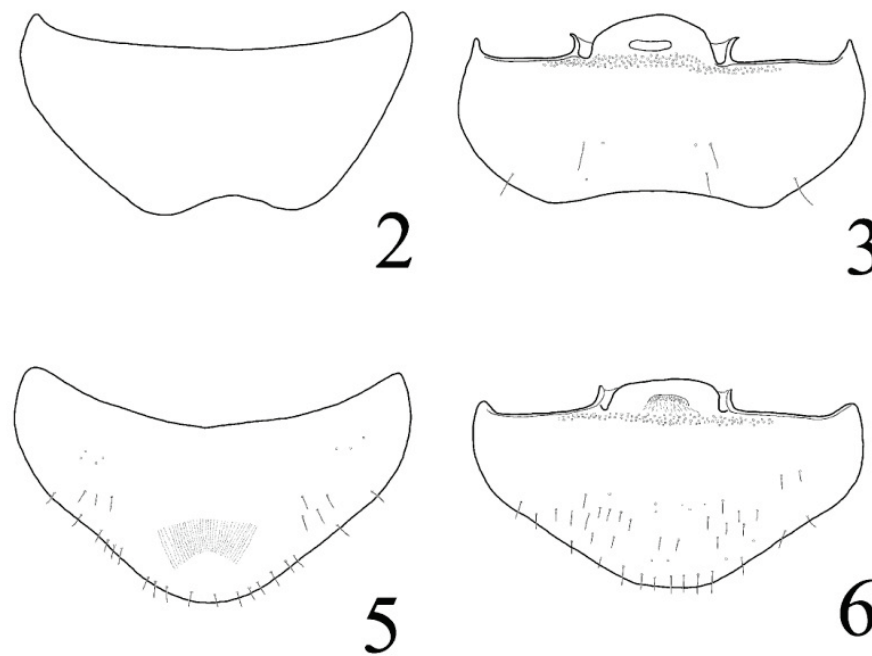

3

6

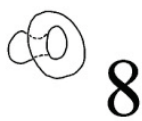

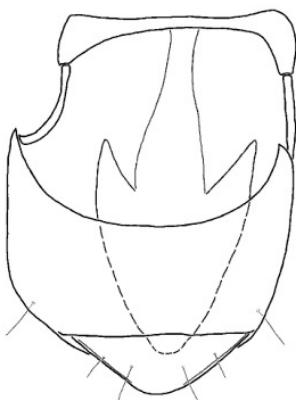

4

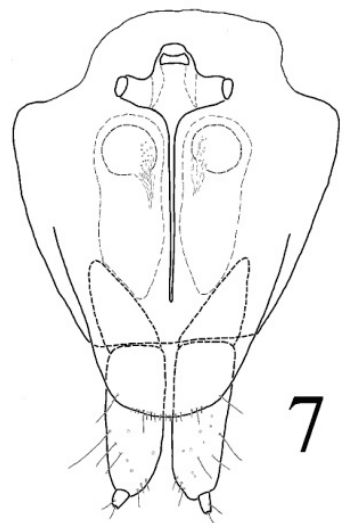

Figs 2-8. Carcinocephalus szujeckii, sp. n.: 2 - male abdominal tergite VIII (dorsal view, holotype), 3 - male abdominal sternite VIII (dorsal view, holotype), 4 - male genital segment (dorsal view, holotype); 5 - female abdominal tergite VIII (dorsal view, paratype), 6 - female abdominal sternite VIII (dorsal view, paratype), 7 - female genital segment with accessory sclerite (ventral view, paratype), 8 - spermatheca (ventral view, paratype). Scale bar for all figures: $0.10 \mathrm{~mm}$. 
Abdomen convex, slightly narrower than elytra, with wide paratergites III-VI, large transverse tomentose spots on middle part of tergite IV and indistinct palisade fringe on apical margin of tergite VII.

Male. Protarsomeres 1-4 slightly widened; all femora evenly widened apicad. Apical margin of abdominal tergite VIII with moderately deep semicircular emargination (Fig. 2). Abdominal sternite VIII with wide emargination (Fig. 3). Genital segment as in Fig. 4. Aedeagus (Figs 9-10) with broad basal part gradually narrowed toward apex, with paired large dorsal lobes on sides of apical part of median lobe; parameres cylindrical, narrow and slightly asymmetric in apical part, significantly exceeding apex of median lobe, with two short apical and two lateral setae on medial margins of parameres; internal sac with two apical fields of elongated thorns, paired latero-basal and median fields of thorns, and with elongated sclerite visible on high magnification within sclerotized basal half of internal sac. Aedeagus laterally as in Fig. 10.

Female. Protarsomeres 1-4 of and femora not widened. Apical margins of abdominal tergite VIII (Fig. 5) and sternite VIII (Fig. 6) rounded. Genital segment and accessory sclerite as in Fig. 7. Spermatheca as in Fig. 8.
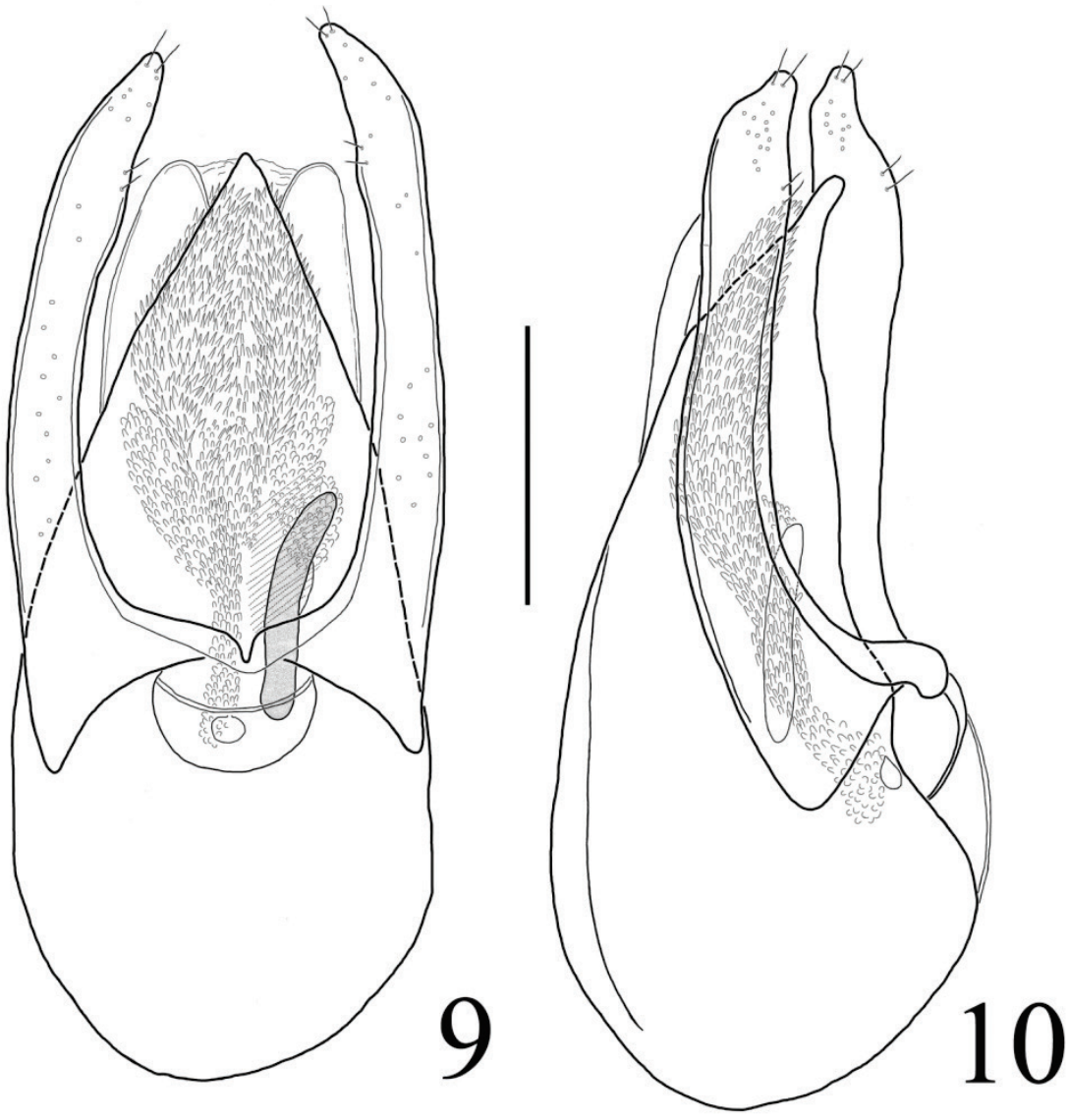

Figs 9-10. Aedeagus (holotype) of Carcinocephalus szujeckii, sp.n.: 9 - parameral view, 10 - lateral view. Scale bar for all figures: $0.10 \mathrm{~mm}$ 
Comparative notes. Carcinocephalus szujeckii sp. n. differs from all congeners by the very small body not exceeding $2 \mathrm{~mm}$, by the presence of moderately strong transverse microsculpture on pronotum and elytra, and by the shape and structure of the internal sac of the aedeagus and by the slightly asymmetric apical parts of significantly elongated parameres. Based on the coloration of body, shape of head, pronotum and apical part of antenna, as well as on the punctation of forebody, C. szujeckii sp. n. is similar to C. blandus, from which it differs by markedly wider antennomere 2 , shorter antennomeres $2-5$, more convex middle elevation of the head and less protruded anterior angles of the pronotum. Based on the shape of head, punctation of the forebody, general shape of the aedeagus and morphological details of the female genital segment (compare Figs 29 a, b in Thayer (1992) and Fig. 7), C. szujeckii sp. n. is similar to wing-dimorphic $C$. flavidus, from which it differs by the shorter body, more transverse pronotum and by the shape of antenna. From the remaining two species, C. szujeckii sp.n. is additionally separated as follows: from wing-dimorphic C. merkli by the shape of antennomeres, smaller and denser punctation of the narrower pronotum; from C. satoi by the paler coloration and significantly smaller punctation of the forebody, by the shorter temples and shapes of antennomeres, by the distinctly transverse pronotum, by the shorter elytra and significantly elongated parameres.

Bionomics. The beetles were found crawling on the rails of a narrow gauge forest railway close to bags of decaying plant fertilizer (dried chicken droppings) [T25] (A. Smetana, pers. comm.).

Etymology. Patronymic, the species was named in honor of the renowned Polish staphylinidologist Andrzej Szujecki (1929-2017).

\section{ACKNOWLEDGEMENTS}

I wish to thank my colleagues A. Smetana (Ottawa) for making the material available for my studies, Alexander Anishchenko (Daugavpils) for help in preparation of the photograph of habitus, and Josh J. Shaw (Copenhagen) for correction of the English text of the manuscript. Sincere thanks are due to two anonymous reviewers for helpful comments and suggestions.

\section{REFERENCES}

Assing V. 2009. On the Western Palaearctic species of Carcinocephalus (Coleoptera: Staphylinidae: Omaliinae). Linzer biologische Beitrage 41 (1): 463-469.

BERnAHUER M. 1902. Beitrag zur Staphylinidenfauna des palaearctischen Gebietes. Münchener Koleopterologische Zeitschrift 1: 54-62.

BERNAHUER M. 1903. Zwölfte Folge neuer Staphyliniden der paläarktischen Fauna, nebst Bemerkungen. Verhandlungen der Kaiserlich-Königlichen Zoologisch-Botanischen Gesellschaft in Wien 53: 591-596.

HAYASHI Y. 2007. A new Japanese species of the genus Carcinocephalus (Coleoptera, Staphylinidae, Omaliinae). Elytra 35 (1): 48-54.

Newton A. F., Thayer M. K., Ashe J. S. \& Chandler D. S. 2000. 22. Staphylinidae Latreille, 1802. In: Arnett R. H. \& Thomas M. C. (eds): American Beetles, Vol. 1. Archostemata, Myxophaga, Adephaga, Polyphaga: Staphyliniformia. Pp. 272-418.

ScheERPeltz O. 1934. Die Gattung Carcinocephalus Bernh. nebst Bemerkungen über das Omaliinen-Subgenus Scribaia Luze (Col. Staphylinidae). Koleopterologische Rundschau 20: 81-94.

SzÉKESSY W. (1963) Holyvák I.-Staphylinidae I. VII kötet (Coleoptera II) 5. füzet. 172 ábrával. Magyarország Állatvilága [Fauna Hungariae]. 66. Akadémiai Kiadó, Budapest, 117 pp.

THAYER M. K. 1992. Discovery of sexual wing dimorphism in Staphylinidae (Coleoptera): “Omalium” flavidum, and a discussion of wing dimorphism in insects. Journal of the New York Entomological Society 100(4): 540-573.

Tо́тн L. 1982. Magyarország Állatvilága-Fauna Hungariae, Holyvák II. -Staphylinidae II VII. Akadémiai Kiadó, Budapest, $110 \mathrm{pp}$.

ZANETTI A. 1987. Coleoptera. Staphylinidae. Omaliinae. Fauna d'Italia [Calderini, Bologna] 25, i-xii + 1-472. 


\section{STRESZCZENIE}

[Nowy gatunek $\mathrm{z}$ rodzaju Carcinocephalus Bernhauer (Coleoptera: Staphylinidae: Omaliinae: Omaliini) z Tajwanu]

Nowy gatunek z rodzaju Carcinocephalus Bernhauer, 1903 został opisany z Tajwanu (Chiai Hsien, Alishan): C. szujeckii sp. n. Opis morfologiczny zawiera zdjęcie przedstawiające ogólny wygląd nowego chrząszcza oraz rysunki końcowych segmentów odwłoka samca i samicy, aedeagus oraz struktur genitalnych samicy. Nowy gatunek odróżnia się od innych z tego rodzaju bardzo małymi rozmiarami ciała, obecnością wyraźnej rzeźby na przedpleczu i pokrywach oraz wewnętrzną i zewnętrzną budową samczych genitaliów. Nowy gatunek jest piątym holarktycznym gatunkiem opisanym w rodzaju Carcinocephalus. 